\title{
A Laccase with Antiproliferative and HIV-I Reverse Transcriptase Inhibitory Activities from the Mycorrhizal Fungus Agaricus placomyces
}

\author{
Jian Sun, ${ }^{1,2}$ Qing-Jun Chen,, ${ }^{1}$ Qing-Qin Cao, ${ }^{1}$ Ying-Ying Wu, ${ }^{2}$ Li-Jing Xu, ${ }^{2}$ Meng-Juan Zhu, ${ }^{2}$ \\ Tzi-Bun $\mathrm{Ng}^{3}$ He-Xiang Wang, ${ }^{2}$ and Guo-Qing Zhang ${ }^{1}$ \\ ${ }^{1}$ Key Laboratory of Urban Agriculture (North) of Ministry of Agriculture, Beijing University of Agriculture, Beijing 102206, China \\ ${ }^{2}$ State Key Laboratory for Agrobiotechnology and Department of Microbiology, China Agricultural University, Beijing 100193, China \\ ${ }^{3}$ School of Biomedical Sciences, The Chinese University of Hong Kong, Hong Kong, China
}

Correspondence should be addressed to He-Xiang Wang, hxwang@cau.edu.cn and Guo-Qing Zhang, zhanggq1001@gmail.com

Received 15 July 2012; Revised 2 August 2012; Accepted 8 August 2012

Academic Editor: Guihua H. Bai

Copyright ( $) 2012$ Jian Sun et al. This is an open access article distributed under the Creative Commons Attribution License, which permits unrestricted use, distribution, and reproduction in any medium, provided the original work is properly cited.

\begin{abstract}
A novel $68 \mathrm{kDa}$ laccase was purified from the mycorrhizal fungus Agaricus placomyces by utilizing a procedure that comprised three successive steps of ion exchange chromatography and gel filtration as the final step. The monomeric enzyme exhibited the N-terminal amino acid sequence of DVIGPQAQVTLANQD, which showed only a low extent of homology to sequences of other fungal laccases. The optimal temperature for A. placomyces laccase was $30^{\circ} \mathrm{C}$, and optimal $\mathrm{pH}$ values for laccase activity towards the substrates 2,7'-azinobis[3-ethylbenzothiazolone-6-sulfonic acid] diammonium salt (ABTS) and hydroquinone were 5.2 and 6.8 , respectively. The laccase displayed, at $30^{\circ} \mathrm{C}$ and $\mathrm{pH} 5.2, K_{m}$ values of $0.392 \mathrm{mM}$ towards hydroquinone and $0.775 \mathrm{mM}$ towards ABTS. It potently suppressed proliferation of MCF 7 human breast cancer cells and Hep G2 hepatoma cells and inhibited human immunodeficiency virus type 1 (HIV-1) reverse transcriptase (RT) activity with an $\mathrm{IC}_{50}$ of $1.8 \mu \mathrm{M}, 1.7 \mu \mathrm{M}$, and $1.25 \mu \mathrm{M}$, respectively, signifying that it is an antipathogenic protein.
\end{abstract}

\section{Introduction}

Laccase (E.C. 1.10.3.2), a polyphenol oxidase containing copper atoms in its catalytic center that plays a key role in lignin degradation in nature, was first demonstrated in plants at the end of 19th century $[1,2]$. It is widely distributed among plants, insects, bacteria, and especially fungi [3]. With a research history of more than a century, laccase has gained importance as a versatile industrial enzyme with a repertoire of applications in lignin degradation, environmental detoxification, and a variety of industries including paper, textile, bioremediation, biocatalysis, diagnostic, and food industries $[4,5]$. Studies on laccases have mainly focused on characterization in terms of molecular mass, protein sequence, $\mathrm{pH}$ and temperature optima, enzyme kinetics, substrate specificity, purification protocol, cloning, structure, applications, and chemical synthesis $[1,3,6-8]$.
Agaricus placomyces, belonging to Family Agaricaceae, is a species of mycorrhizal fungus widely distributed in Asia, Europe, and North America. It is reportedly edible, but for some people it could cause gastrointestinal problems. Few studies on A. placomyces except those on its toxic components have been published [9]. On the other hand, articles about laccases from the same genus Agaricus, for example, laccases from A. bisporus [10] and A. blazei [11], are available. The objective of the present study was to isolate a laccase from $A$. placomyces and investigate its characteristics.

\section{Materials and Methods}

2.1. Materials and Reagents. Fruiting bodies of A. placomyces were collected in the forest of Baiwangshan National Forest Park (Beijing, China) and authenticated by experts in 
the Department of Microbiology and Immunology, College of Biosciences, China Agricultural University. DEAEcellulose, CM-cellulose, Trizma-base, 2,7'-azinobis[3ethylbenzothiazolone-6-sulfonic acid] diammonium salt (ABTS), catechol, hydroquinone, 2-methylcatechol, N,N-Dimethyl-1,4-phenylenediamine, pyrogallol, and tyrosine were purchased from Sigma, USA. Q-Sepharose and molecular mass standards were obtained from GE Healthcare, USA. MCF 7 tumor cell lines and Hep G2 tumor cell lines were purchased from the American Type Culture Collection, USA. All other reagents used were of reagent grade and from China unless otherwise mentioned.

2.2. Isolation of Laccase. Fresh fruiting bodies of A. placomyces $(500 \mathrm{~g})$ were homogenized in distilled water $(1: 4$, $\mathrm{w} / \mathrm{v})$ and then extracted overnight at $4^{\circ} \mathrm{C}$. The homogenate was subsequently centrifuged $(12000 \mathrm{~g})$ at $4^{\circ} \mathrm{C}$ for $20 \mathrm{~min}$. The supernatant was further purified by three successive steps of ion exchange chromatography, first on DEAEcellulose $\left(10 \mathrm{mM} \mathrm{NH}_{4} \mathrm{HCO}_{3}\right.$ buffer, $\left.\mathrm{pH} 9.4\right)$, then on CMcellulose (10 mM sodium acetate buffer, $\mathrm{pH} 5.2$ ), and finally on Q-Sepharose (10 mM Tris- $\mathrm{HCl}$ buffer, $\mathrm{pH}$ 8.0). The active fraction was ultimately purified by fast protein liquid chromatography (FPLC) on a Superdex 75 HR 10/30 gel filtration column (0.15 $\mathrm{M} \mathrm{NH}_{4} \mathrm{HCO}_{3}$ buffer, $\mathrm{pH}$ 8.5) [12].

2.3. Molecular Mass Determination by SDS-PAGE and FPLC Gel Filtration. Sodium dodecyl sulfate-polyacrylamide gel electrophoresis (SDS-PAGE) was carried out using a $12 \%$ resolving gel and a 5\% stacking gel [13]. At the end of electrophoresis, the gel was stained with Coomassie brilliant blue R-250. FPLC-gel filtration was carried out using a Superdex 75 column that had been calibrated with molecular mass standards [14].

2.4. Determination of N-Terminal Amino Acid Sequence of Isolated Laccase. Amino acid sequence analysis was carried out using an HP G1000A Edman degradation unit and an HP1000 HPLC system [12].

2.5. Assay of Laccase Activity. Laccase activity was assayed by measuring the oxidation of 2,7'-azinobis[3ethylbenzothiazolone-6-sulfonic acid] diammonium salt (ABTS). A modification of the method of Shin and Lee was used [15]. In brief, $5 \mu \mathrm{L}$ laccase solution was incubated with $140 \mu \mathrm{L} 1 \mathrm{mM}$ ABTS (in $50 \mathrm{mM}$ sodium acetate buffer, $\mathrm{pH}$ 5.2) at $30^{\circ} \mathrm{C}$ for $5 \mathrm{~min}$. Subsequently, the reaction was ended by adding $255 \mu \mathrm{L} \mathrm{10 \%} \mathrm{(w/v)} \mathrm{trichloroacetic} \mathrm{acid.} \mathrm{One} \mathrm{unit}$ of enzyme activity was defined as the amount of enzyme required to produce an absorbance increase at $405 \mathrm{~nm}$ of $1 / \mathrm{min} / \mathrm{mL}$ of reaction mixture under the aforementioned conditions. All determinations were performed in triplicate.

2.6. Determination of Temperature Optimum and Thermostability of Isolated Laccase. To determine the temperature optimum of A. placomyces laccase, the standard laccase assay mentioned above was conducted over a temperature range of $10-80^{\circ} \mathrm{C}$. In the thermostability assay, enzyme solutions were incubated at various temperatures $\left(20,40,60,70\right.$, and $\left.80^{\circ} \mathrm{C}\right)$ and for various durations $(0,10,20,30,40,50$, and $60 \mathrm{~min})$, respectively. The residual activity was measured using the standard assay after the enzyme solutions had been cooled down to room temperature.

2.7. Determination of pH Optimum of Isolated Laccase. In the assay for determining optimal $\mathrm{pH}$, two substrates, ABTS and hydroquinone, and a series of substrate solutions in buffers with different $\mathrm{pH}$ values were used. The assay buffers were prepared in $50 \mathrm{mM} \mathrm{Na} \mathrm{HPO}_{4}$-citric acid buffers ( $\mathrm{pH} 2.4-$ 8.0). The assay temperature was $30^{\circ} \mathrm{C}$.

2.8. Assay of Substrate Specificity of Isolated Laccase and Enzyme Kinetics. To determine the substrate specificity of the purified laccase, several aromatic substrates (at $5.0 \mathrm{mM}$ concentration) other than ABTS were used in the enzyme assay. The substrates tested comprised ABTS, catechol, hydroquinone, 2-methyl-catechol, N,N-dimethyl1,4-phenylenediamine, pyrogallol, and tyrosine. Equal volumes of substrate solutions and buffers were mixed as the assay substrate solutions. The substrate oxidation rate was followed by measuring the change in absorbance using the molar extinction coefficient $(e)$ obtained from the literature [5]. In the enzyme kinetics assay, the Michaelis-Menten constants $\left(K_{m}\right)$ were determined at $30^{\circ} \mathrm{C}$ using ABTS and hydroquinone dissolved in sodium acetate buffer $(50 \mathrm{mM}$, $\mathrm{pH}$ 5.2) as substrates. The $K_{m}$ value was determined from a Lineweaver-Burk plot [2].

2.9. Effects of Metal Ions and Chemical Reagents on Enzyme Activity of Isolated Laccase. The effects of different metal chlorides and chemical reagents were tested at the final concentrations of $1.25,2.5$, and $5.0 \mathrm{mM}$, respectively. The purified enzyme solution was preincubated with the metal ions or chemical reagents at $4^{\circ} \mathrm{C}$ for $60 \mathrm{~min}$ before the standard laccase assay was performed. The control did not contain metal ions or chemical reagents.

2.10. Assay of Antiproliferative Activity and HIV-1 Reverse Transcriptase Inhibitory Activity of Isolated Laccase. Antiproliferative activity of the purified laccase towards MCF 7 human breast cancer and Hep G2 hepatoma cell lines was determined using the MTT assay [14]. Inhibitory activity toward human immunodeficiency virus type 1 (HIV-1) reverse transcriptase (RT) was determined by using the assay kit from the Boehringer-Mannheim (Germany) and following the standard protocol of Zhang et al. [2].

\section{Results}

3.1. Isolation of Laccase. A. placomyces laccase was purified with a protocol that entailed three consecutive steps of ion exchange chromatography and a single step of gel filtration, resulting in a $14.42 \%$ recovery of activity and a purification factor of 43.7-fold (Table 1). The crude extract was resolved into three fractions: D1, D2, and D3 after elution with 0 , 300 , and $1000 \mathrm{mM} \mathrm{NaCl}$, respectively, in $\mathrm{NH}_{4} \mathrm{HCO}_{3}$ buffer 
TABLE 1: Yields and laccase activities at each purification step (from $500 \mathrm{~g}$ A. placomyces fresh fruiting body, activity assayed at $30^{\circ} \mathrm{C}$ ).

\begin{tabular}{lccccc}
\hline Purification step & Yield $(\mathrm{mg})$ & Specific activity $(\mathrm{U} / \mathrm{mg})$ & Total activity $(\mathrm{U})$ & Recovery of activity $(\%)$ & Purification fold \\
\hline Crude Extract & 12927.00 & 29.9 & 386468.93 & 100.00 & 73.74 \\
DEAE-cellulose & 1150.92 & 247.61 & 284977.8 & 45.57 & 8.3 \\
CM-cellulose & 184.67 & 625.86 & 115577.6 & 18.83 & 30.9 \\
Q-Sepharose & 61.29 & 1187.65 & 52791.1 & 14.42 & 43.7 \\
FPLC on a Superdex 75 & 42.69 & 1305.16 & 55717.3 & & \\
\hline
\end{tabular}

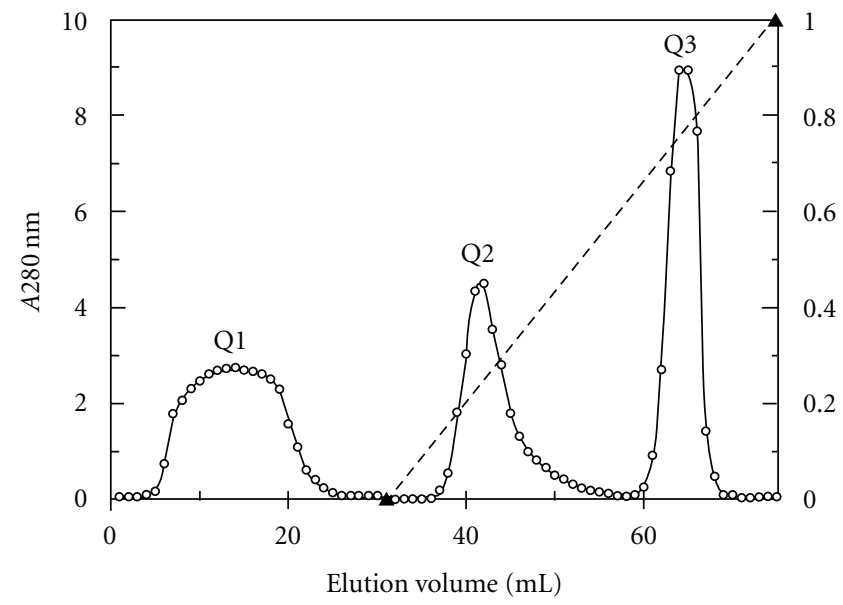

(a)

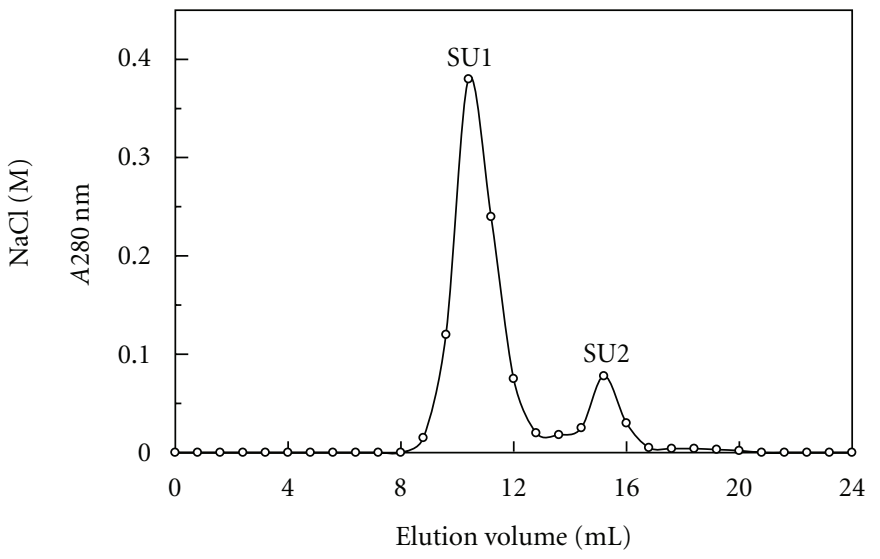

(b)

Figure 1: Elution profiles of A. placomyces laccase. (a) Ion exchange chromatography on Q-Sepharose column. Fraction Q2 is the laccase active fraction. (b) Gel filtration on Superdex 75. Fraction SU1 represents purified laccase.

(10 mM, pH 9.4). Fraction D2 with laccase activity was further purified by adsorption on CM-cellulose and eluted as fraction $\mathrm{C} 2$ with $50 \mathrm{mM} \mathrm{NaCl}$ in the elution buffer (pH 5.2). Subsequently, fraction C2 was applied to QSepharose and eluted with a linear gradient of $0-1 \mathrm{M} \mathrm{NaCl}$. Laccase activity was concentrated in fraction Q2 (Table 1 and Figure 1(a)). Fraction Q2 was separated, upon FPLC on Superdex 75, into a large peak (SU1) with laccase activity and a small peak (SU2) devoid of laccase activity (Table 1 and Figure 1(b)).

\subsection{Determination of Molecular Mass and N-Terminal} Sequence. Based on a comparison of its volume of elution from the Superdex 75 column with those of molecular mass standards, SU1 manifested a molecular mass of $68 \mathrm{kDa}$ (data not shown). SDS-PAGE showed a single band with the same molecular mass (Figure 2). It indicated that the laccase is a monomeric protein with a molecular mass of $68 \mathrm{kDa}$. Its $\mathrm{N}$ terminal amino acid sequence was DVIGPQAQVTLANQD (UniProt accession number: B3EWI3). A comparison of $\mathrm{N}$-terminal amino acid sequence of $A$. placomyces laccase with other mushroom laccases is presented in Table 2. The purified laccase showed little N-terminal amino acid sequence homology to other mushroom laccases.

3.3. Characteristics of A. placomyces Laccase. An optimal temperature of $30^{\circ} \mathrm{C}$ was required for the purified A. placomyces

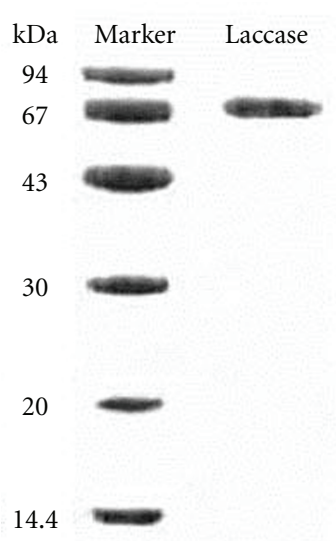

FIgURE 2: SDS-PAGE of A. placomyces laccase.

laccase to express maximal activity. The activity underwent a sharp decline as the temperature was increased from $40^{\circ} \mathrm{C}$ to $80^{\circ} \mathrm{C}$. Laccase activity vanished when the temperature reached $80^{\circ} \mathrm{C}$ (Figure $3(\mathrm{a})$ ). The purified enzyme was stable below $40^{\circ} \mathrm{C}$ and a decline of laccase activity was noted, when the enzyme was incubated at $60^{\circ} \mathrm{C}$ for $10-60 \mathrm{~min}$. After incubation for one hour at $70^{\circ} \mathrm{C}$, about $20 \%$ of the maximal activity remained. When the laccase was preincubated at 
TABLE 2: Comparison of the N-terminal sequence of A. placomyces laccase with other fungal laccases.

\begin{tabular}{|c|c|}
\hline Species & N-terminal sequence \\
\hline Agaricus placomyces (B3EWI3, this study) & 1 DVIGP QAQVT LANQQD 15 \\
\hline Agaricus bisporus (AAC18877.1) & 491 NVSSGP QSQIT PQDWL 506 \\
\hline Agaricus bisporus (ACR19861.1) & 34 KTIGP VGTIT IANKE 48 \\
\hline Cerrena unicolor (ACL93462.1) & 20 LAIGP VADDLH ITDDT 34 \\
\hline Coriolopsis gallica (ACS26245.1) & 20 AAIGP VADLT ISNGA 34 \\
\hline Ganoderma lucidum (ACR24357.1) & 20 ADIGP KADLT ISNAN 34 \\
\hline Lentinula edodes (AAF13038.1) & 189 AAVAP P PADAT LINGK 203 \\
\hline Phlebia radiata (CAI56705.1) & 22 SGIGP VTDLR ISNAV 36 \\
\hline Pleurotus eryngii (ADG01835.1) & 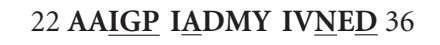 \\
\hline Pleurotus ostreatus (AAR21094.1) & 22 AAIGP TGNMY IVNED 36 \\
\hline Trametes trogii (CAC13040.1) & 20 AAIGP VADLT ISNGGA 34 \\
\hline
\end{tabular}

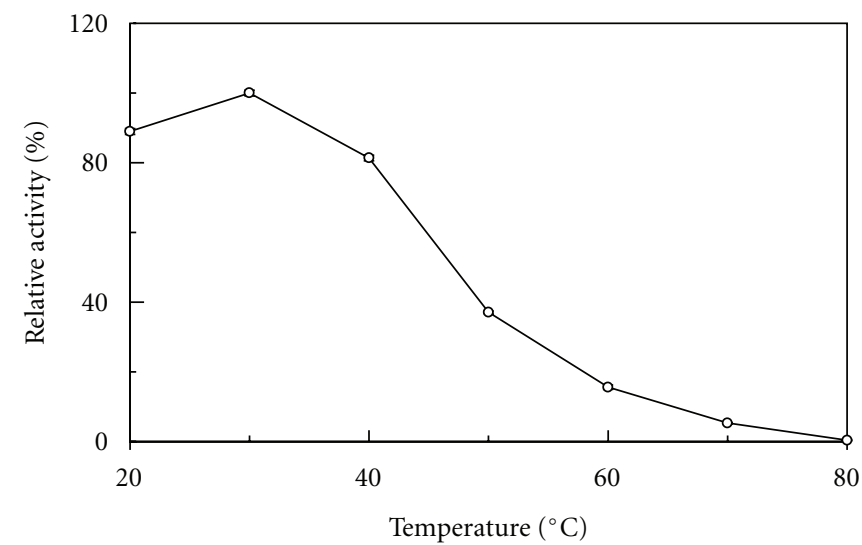

(a)

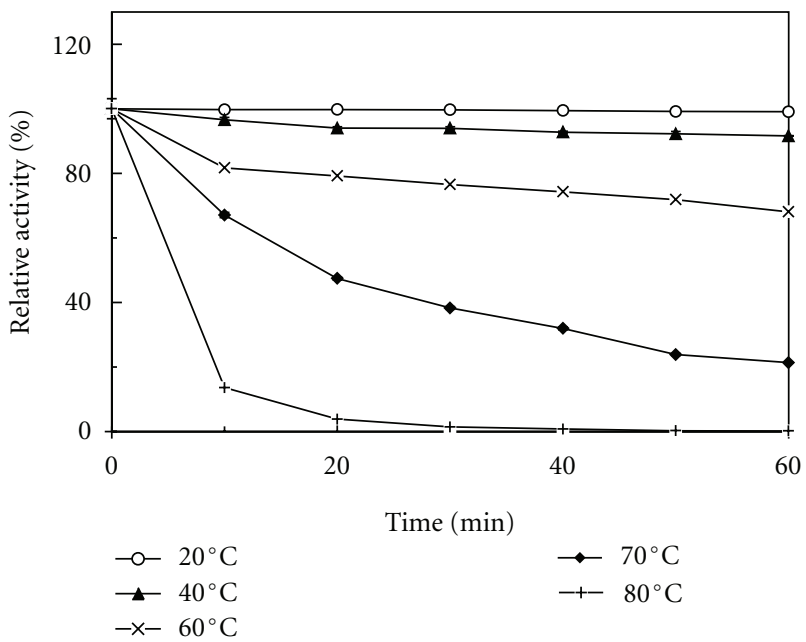

(b)

Figure 3: Temperature optimum and thermal stability of A. placomyces laccase. (a) Effect of temperature on A. placomyces laccase. (b) A. placomyces laccase.

$80^{\circ} \mathrm{C}$ for more than $20 \mathrm{~min}$, it lost almost all the enzyme activity (Figure $3(\mathrm{~b})$ ).

The purified A. placomyces laccase exhibited optimal $\mathrm{pH}$ values of 5.2 and 6.8 towards ABTS and hydroquinone, respectively (Figure 4). When the ambient $\mathrm{pH}$ was raised to 5.5 (towards ABTS) or 7.0 (towards hydroquinone), an abrupt decrement in enzyme activity took place. The degradative activity towards ABTS dropped further at $\mathrm{pH} 6.0$ 


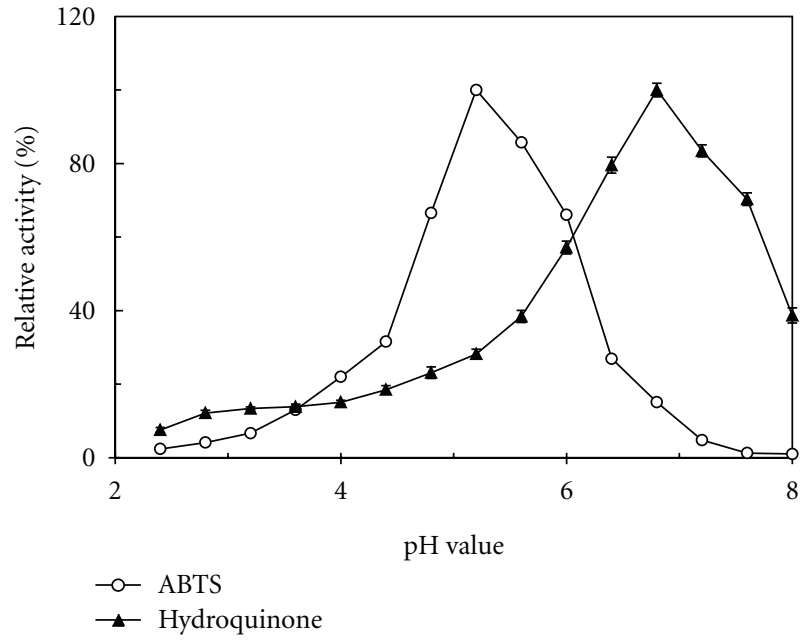

Figure 4: pH optimum of A. placomyces laccase.

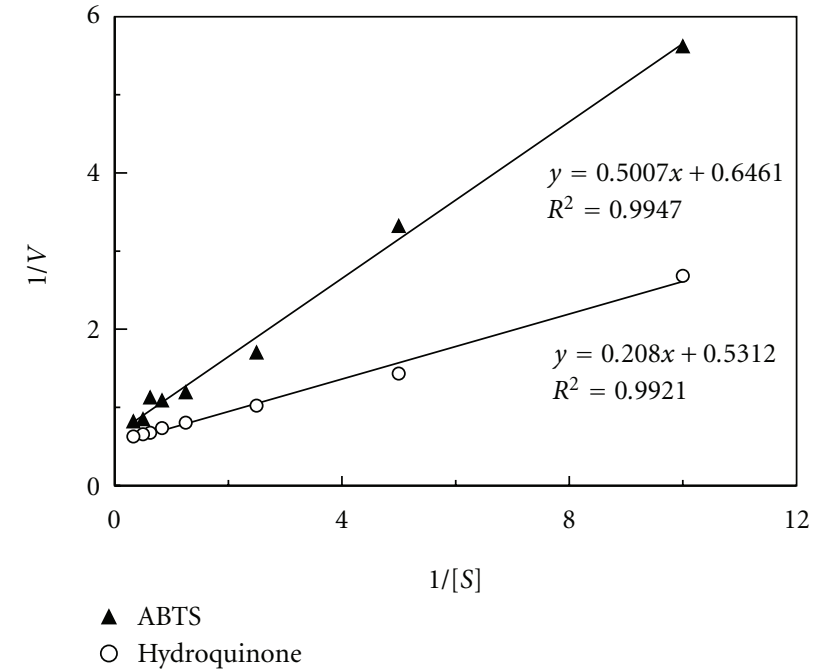

Figure 5: The Lineweaver-Burk plots of A. placomyces laccase. and decreased to an undetectable level at $\mathrm{pH}$ 7.6. About $40 \%$ of total activity towards hydroquinone remained when the $\mathrm{pH}$ value increased to 8.0 (Figure 4).

A. placomyces laccase oxidized a variety of substrates, including polyphenols (hydroquinone, pyrogallol, catechol), methoxy-substituted phenols (2-methylcatechol), aromatic diamines (N,N-dimethyl-1,4-phenylenediamine), and the nonphenolic heterocyclic compound ABTS. The highest degradative activity was demonstrated towards hydroquinone, $77 \%$ as much activity was observed towards ABTS, and 54\% activity towards N,N-dimethyl-1,4phenylenediamine. Activity towards other substrates was considerably attenuated or indiscernible: 9\% activity towards pyrogallol, $3 \%$ activity towards catechol, $1 \%$ activity towards 2-methyl-catechol, and undetectable activity towards tyrosine. The $K_{m}$ values at $30^{\circ} \mathrm{C}$ and $\mathrm{pH} 5.2$ towards hydroquinone and ABTS were $0.392 \mathrm{mM}$ and $0.775 \mathrm{mM}$, respectively (using the Lineweaver-Burk plots, Figure 5).

The laccase activity was not significantly affected by the presence of cations such as $\mathrm{K}^{+}, \mathrm{Ca}^{2+}, \mathrm{Mg}^{2+}, \mathrm{Mn}^{2+}$, and $\mathrm{Zn}^{2+}$ ions at the concentrations of $1.25-5.0 \mathrm{mM}$. However, the activity was reduced in the presence of $\mathrm{Cu}^{2+}, \mathrm{Hg}^{2+}, \mathrm{Pb}^{2+}$, and $\mathrm{Fe}^{3+}$ ions and also EDTA. $\mathrm{Al}^{3+}$ ions could enhance the enzyme activity by $14-57 \%$ at the concentrations of 1.25-2.5 mM (Table 3). A. placomyces laccase demonstrated antiproliferative activity towards MCF 7 and Hep G2 tumor cell lines and inhibitory activities towards HIV-1 reverse transcriptase. At the concentrations of $0.25 \mu \mathrm{M}, 0.5 \mu \mathrm{M}$, $1.0 \mu \mathrm{M}, 2.0 \mu \mathrm{M}$, and $4.0 \mu \mathrm{M}$, the purified laccase inhibited proliferation of MCF 7 cells by $4.5 \%, 13.9 \%, 33.6 \%, 52.3 \%$, and $77.2 \%$, respectively, and Hep G2 cells by $10.1 \%, 18.3 \%$, $34.2 \%, 54.4 \%$, and $70.0 \%$, respectively. The $\mathrm{IC}_{50}$ values against MCF 7 and Hep G2 cells were $1.8 \mu \mathrm{M}$ and $1.7 \mu \mathrm{M}$, respectively. The purified laccase inhibited the activity of HIV-1 reverse transcriptase with an $\mathrm{IC}_{50}$ value of $1.25 \mu \mathrm{M}$. A comparison of characteristics of laccases from A. bisporus [10], A. blazei [11], and A. placomyces (this study) is shown in Table 4.

\section{Discussion}

A. placomyces is a common edible wild mushroom widely distributed in China. Hitherto there is a lack of literature pertaining to physiologically active substances in this mushroom species. In the present investigation, a laccase, which is endowed with suppressive activity towards MCF 7 cells $\left(\mathrm{IC}_{50}\right.$ value $\left.=1.8 \mu \mathrm{M}\right)$ and Hep G2 cells $\left(\mathrm{IC}_{50}\right.$ value $=1.7 \mu \mathrm{M})$, and HIV-1 RT inhibitory activity $\left(\mathrm{IC}_{50}\right.$ value $=$ $1.25 \mu \mathrm{M}$ ), has been successfully isolated from A. placomyces fruiting bodies. The laccase presents as a single band with a molecular mass of $68 \mathrm{kDa}$ in SDS-PAGE. The molecular mass falls well within the molecular mass range of the bulk of previously reported fungal laccases $(50-90 \mathrm{kDa})$ [1]. The molecular mass of $A$. placomyces laccase is very close to those of A. bisporus [16] and A. blazei [11], which are $65 \mathrm{kDa}$ and $66 \mathrm{kDa}$, respectively. On the other hand, another laccase from $A$. bisporus manifests a molecular mass of $100 \mathrm{kDa}$ with a carbohydrate content of $15 \%$ [10]. The purified A. placomyces laccase is a monomeric protein just like laccases from Abortiporus biennis [5], A. bisporus [16], A. blazei [11], Cladosporium cladosporioides [17], Clitocybe maxima [2], and Pleurotus sajor-caju [18]. However, it is different from multimeric laccases from Pleurotus ostreatus [19] and Scytalidium thermophilum [20]. The purified laccase demonstrates low homology in $\mathrm{N}$-terminal amino acid sequence to other mushroom laccases.

The present laccase manifests optimal $\mathrm{pH}$ values of $\mathrm{pH}$ 5.2 towards ABTS and $\mathrm{pH} 6.8$ towards hydroquinone, which are slightly higher than that of other laccases. Most fungal laccases demonstrate an optimal $\mathrm{pH}$ value range of 2.04.8 towards ABTS [1], such as A. biennis ( $\mathrm{pH} 3.0-4.0)$ [5], A. blazei ( $\mathrm{pH}$ 2.3) [11], Lentinus edodes ( $\mathrm{pH}$ 4.0) [12], Agrocybe cylindracea ( $\mathrm{pH} 3.0-4.0)$ [21], C. cladosporioides ( $\mathrm{pH}$ 3.5) [17], and Tricholoma mongolicum ( $\mathrm{pH}$ 2.0-3.0) [22]. It suggests that $A$. placomyces laccase manifests a potential application at higher ambient $\mathrm{pH}$ near neuter, which is more stable for enzymes maintaining their activities. 
TABLE 3: Effect of metals and chemical reagents on the activity of A. placomyces laccase.

\begin{tabular}{lccc}
\hline Metal ion & & Relative activity (\% of control) & $2.5 \mathrm{mM}$ \\
\hline $\mathrm{K}^{+}$ & $1.25 \mathrm{mM}$ & 92 & $5.0 \mathrm{mM}$ \\
$\mathrm{Ca}^{2+}$ & 93 & 108 & 106 \\
$\mathrm{Cu}^{2+}$ & 105 & 65 & 71 \\
$\mathrm{Hg}^{2+}$ & 58 & 34 & 25 \\
$\mathrm{Mg}^{2+}$ & 45 & 99 & 99 \\
$\mathrm{Mn}^{2+}$ & 105 & 108 & 109 \\
$\mathrm{~Pb}^{2+}$ & 105 & 55 & 56 \\
$\mathrm{Zn}^{2+}$ & 52 & 91 & 86 \\
$\mathrm{Al}^{3+}$ & 96 & 60 & 114 \\
$\mathrm{Fe}^{3+}$ & 157 & 47 & 47 \\
EDTA & 68 & 61 & 32 \\
\hline
\end{tabular}

Laccase activity in the absence of chemical reagents was regarded as $100 \%$.

TABle 4: Characteristic comparison of laccases from A. bisporus [10], A. blazei [11], and A. placomyces (this study).

\begin{tabular}{lccc}
\hline & A. bisporus [10] & A. blazei [11] & A. placomyces (this study) \\
\hline Molecular mass (kDa) & 100 & 66 & 68 \\
Molecular structure & Monomeric & Monomeric & Monomeric \\
N-terminal sequence & - & - & DVIGPQAQVTLANQD \\
$K_{m}$ value & - & $0.063 \mathrm{mM}$ for ABTS & $0.392 \mathrm{mM}$ for hydroquinone \\
& 5.6 for & $1.03 \mathrm{mM}$ for 2,6-DMP & $0.775 \mathrm{mM}$ for ABTS \\
Optimal pH & - -phenylenediamine & 2.3 for ABTS & 6.8 for hydroquinone \\
Optimal temperature & - & 5.5 for 2,6-DMP & 5.2 for ABTS \\
Antiproliferative activity & - & $20^{\circ} \mathrm{C}$ & $30^{\circ} \mathrm{C}$ \\
towards tumor cell lines & - & - & $1.8 \mu \mathrm{M}$ of $\mathrm{MCF} 7$ \\
HIV-1 RT inhibitory & - & - & $1.7 \mu \mathrm{M}$ of Hep G2 \\
activity $\left(\right.$ IC $_{50}$ ) & & & $1.25 \mu \mathrm{M}$
\end{tabular}

“-”: no database.

A. placomyces laccase demonstrates a low temperature optimum at $30^{\circ} \mathrm{C}$ and a sharp decline in enzyme activity at temperatures higher than than $30^{\circ} \mathrm{C}$, thus the purified laccase is quite thermo sensitive. Similar research has been reported on the laccase from A. blazei, which is stable at $20^{\circ} \mathrm{C}$, but loses activity rapidly at $40^{\circ} \mathrm{C}[11]$. A placomyces laccase has nearly $80 \%$ of total activity remaining after incubation for one hour at $60^{\circ} \mathrm{C}$, while $A$. blazei laccase loses $90 \%$ of total activity after incubation at $60^{\circ} \mathrm{C}$ for half an hour. The laccase from A. bisporus remains completely stable at $40^{\circ} \mathrm{C}$ and below for at least $24 \mathrm{~h}$ and undergoes a $50 \%$ loss of total activity after $10 \mathrm{~min}$ at $70^{\circ} \mathrm{C}, 40 \mathrm{~min}$ at $60^{\circ} \mathrm{C}$, and $3 \mathrm{~h}$ at $50^{\circ} \mathrm{C}$ [10]. On the contrary, many other laccases possess higher temperature optima, including A. biennis $\left(60^{\circ} \mathrm{C}\right)$ [5], Albatrellus dispansus $\left(70^{\circ} \mathrm{C}\right)[23]$, C. maxima $\left(60^{\circ} \mathrm{C}\right)[2]$, and Ganoderma lucidum $\left(70^{\circ} \mathrm{C}\right)[24]$.

In line with laccases reported in the literature, the isolated enzyme manifests degradation activities towards a variety of substrates including ABTS, aromatic diamines, and phenols. However, in contradistinction to many other laccases which prefer ABTS to hydroquinone, A. placomyces laccase expresses the highest activity towards hydroquinone
$\left(K_{m}\right.$ value $\left.=0.392 \mathrm{mM}\right)$, followed by ABTS with a $K_{m}$ value of $0.775 \mathrm{mM}$. A. biennis laccase manifests an activity towards hydroquinone which is only about $10 \%$ of that towards ABTS $\left(K_{m}=33.5 \mu \mathrm{M}\right)[5]$. The degradative activity of C. maxima laccase towards various substrates differs as follows: activity towards $\operatorname{ABTS}\left(K_{m}=61.7 \mu \mathrm{M}\right)>$ hydroquinone $>$ N,Ndimethyl-1,4-phenylenediamine $>$ pyrogallol $>$ catechol $>2$ methylcatechol [2]. The laccase from $A$. blazei demonstrates $K_{m}$ values of $63 \mu \mathrm{M}$ and $1.03 \mathrm{mM}$ towards ABTS and 2,6dimethoxyphenol (DMP), respectively [11]. Based on the kinetics data, A. blazei laccase appears to be more sensitive towards ABTS than the laccase from A. placomyces.

Many previous studies indicate that laccases can be enhanced by low levels of $\mathrm{Cu}^{2+}$ ions $(0.5-3.5 \mathrm{mM})$. Addition of $1 \mathrm{mM} \mathrm{Cu}^{2+}$ ions increases the activity of $P$. ostreatus laccase by eightfold [25]. $\mathrm{Cu}^{2+}$ ions at $6.25 \mathrm{mM}$ concentration bring about $11.7 \%$ augmentation in activity of $A$. biennis laccase [5]. In the present study, $\mathrm{Cu}^{2+}$ ions in the concentration range of $1.25-5.0 \mathrm{mM}$ reduce the enzyme activity of $A$. placomyces laccase by about $30-40 \%$, reminiscent of the observation that the laccase from Fusarium solani with approximately $30 \%$ inhibition by $\mathrm{Cu}^{2+}$ ions at $20 \mathrm{mM}$ 
concentration [26]. On the other hand, the activity of $C$. maxima laccase is not significantly affected by $\mathrm{Cu}^{2+}$ ions at the concentrations ranging from $6.25 \mathrm{mM}$ to $50 \mathrm{mM}$ [2].

The purified enzyme possesses potential application with inhibitory activities towards MCF 7 and Hep G2 tumor cells and HIV-1 RT. Many fungal lectins manifest antiproliferative activities towards tumor cells, but few laccases are reported to inhibit tumor cell proliferation [27]. Laccases from Hericium coralloides and shiitake mushroom are devoid of antiproliferative activities against Hep G2 or MCF 7 tumor cells at a concentration of $60 \mu \mathrm{M}[12,28]$. Among the laccases with antiproliferative activities towards tumor cells, A. placomyces lacase possesses lower $\mathrm{IC}_{50}$ values. A. biennis laccase demonstrates antiproliferative activities against Hep G2 and MCF-7 cells with $\mathrm{IC}_{50}$ values of $12.5 \mu \mathrm{M}$ and $6.7 \mu \mathrm{M}$, respectively [5]. C. maxima laccase shows antiproliferative activity against Hep G2 and MCF-7 tumor cells with $\mathrm{IC}_{50}$ values of $12.3 \mu \mathrm{M}$ and $3.0 \mu \mathrm{M}$, respectively [2]. It indicates that the present lacccase shows potential applications in cancer treatments.

The mechanism of HIV-1 reverse transcriptase inhibitory activity probably involves protein-protein interaction, analogous to the mechanism of inhibition of the retroviral reverse transcriptase by the homologous protease [29]. Previously, a diversity of bioactive compounds, such as lectins, laccases, and ribonucleases, have been reported to demonstrate HIV-1RT inhibitory activity [27]. A. placomyces laccase exhibits a considerably lower $\mathrm{IC}_{50}$ value against HIV1 reverse transcriptase of $1.25 \mu \mathrm{M}$, compared with those of other laccases, such as A. biennis $(9.2 \mu \mathrm{M})$ [5], A. cylindracea $(12.7 \mu \mathrm{M})$ [21], C. maxima $(14.4 \mu \mathrm{M})$ [2], and Hericium erinaceus $(9.5 \mu \mathrm{M})[30](14.4 \mu \mathrm{M})$. To date, the most potent inhibitor towards HIV-1 RT from laccases is T. mongolicum laccase, which manifests the lowest $\mathrm{IC}_{50}$ value of $0.65 \mu \mathrm{M}$ [22], whereas laccases from Cantharellus cibarius [31] and A. dispansus [23] are devoid of HIV-1 RT inhibitory activity.

It is noteworthy that A. placomyces laccase exhibits antiproliferotive activity towards tumor cells and inhibitory activity toward HIV-1 RT, and manifests a slightly high $\mathrm{pH}$ optimum. It indicates that the enzyme has great potential for medical and industrial applications.

\section{Acknowledgments}

This work was financially supported by the National Grants of China (2010CB732202 and 2012BAD14B09) and the Beijing Innovative Grant of Modern Agricultural Technology System.

\section{References}

[1] P. Baldrian, "Fungal laccases-occurrence and properties," FEMS Microbiology Reviews, vol. 30, no. 2, pp. 215-242, 2006.

[2] G. Q. Zhang, Y. F. Wang, X. Q. Zhang, T. B. Ng, and H. X. Wang, "Purification and characterization of a novel laccase from the edible mushroom Clitocybe maxima," Process Biochemistry, vol. 45, no. 5, pp. 627-633, 2010.

[3] A. M. Mayer and R. C. Staples, "Laccase: new functions for an old enzyme," Phytochemistry, vol. 60, no. 6, pp. 551-565, 2002.
[4] S. Rajeeva and S. S. Lele, "Bioprocessing of laccase produced by submerged culture of Ganoderma sp. WR-1," Separation and Purification Technology, vol. 76, no. 2, pp. 110-119, 2010.

[5] G. Q. Zhang, T. Tian, Y. P. Liu, H. X. Wang, and Q. J. Chen, "A laccase with anti-proliferative activity against tumor cells from a white root fungus Abortiporus biennis," Process Biochemistry, vol. 46, no. 12, pp. 2336-2340, 2011.

[6] C. J. Rodgers, C. F. Blanford, S. R. Giddens, P. Skamnioti, F. A. Armstrong, and S. J. Gurr, "Designer laccases: a vogue for high-potential fungal enzymes?" Trends in Biotechnology, vol. 28, no. 2, pp. 63-72, 2010.

[7] N. Santhanam, J. M. Vivanco, S. R. Decker, and K. F. Reardon, "Expression of industrially relevant laccases: prokaryotic style," Trends in Biotechnology, vol. 29, no. 10, pp. 480-489, 2011.

[8] S. V. Kumar, P. S. Phale, S. Durani, and P. P. Wangikar, "Combined sequence and structure analysis of the fungal laccase family," Biotechnology and Bioengineering, vol. 83, no. 4, pp. 386-394, 2003.

[9] A. Petrova, K. Alipieva, E. Kostadinova et al., "GC-MS studies of the chemical composition of two inedible mushrooms of the genus Agaricus," Chemistry Central Journal, vol. 1, article 33, 2007.

[10] D. A. Wood, "Production, purification and properties of extracellular laccase of Agaricus bisporus," Journal of General Microbiology, vol. 117, no. 2, pp. 327-338, 1980.

[11] R. Ullrich, L. M. Huong, N. L. Dung, and M. Hofrichter, "Laccase from the medicinal mushroom Agaricus blazei: production, purification and characterization," Applied Microbiology and Biotechnology, vol. 67, no. 3, pp. 357-363, 2005.

[12] J. Sun, H. Wang, and T. B. Ng, "Isolation of a laccase with HIV1 reverse transcriptase inhibitory activity from fresh fruiting bodies of the Lentinus edodes (Shiitake mushroom)," Indian Journal of Biochemistry \& Biophysics, vol. 48, no. 2, pp. 88-94, 2011.

[13] U. K. Laemmli and M. Favre, "Maturation of the head of bacteriophage T4. I. DNA packaging events," Journal of Molecular Biology, vol. 80, no. 4, pp. 575-599, 1973.

[14] E. F. Fang, W. L. Pan, J. H. Wong, Y. S. Chan, X. J. Ye, and T. B. Ng, "A new Phaseolus vulgaris lectin induces selective toxicity on human liver carcinoma Hep G2 cells," Archives of Toxicology, vol. 85, no. 12, pp. 1551-1563, 2011.

[15] K. S. Shin and Y. J. Lee, "Purification and characterization of a new member of the laccase family from the white-rot basidiomycete Coriolus hirsutus," Archives of Biochemistry and Biophysics, vol. 384, no. 1, pp. 109-115, 2000.

[16] C. R. Perry, S. E. Matcham, D. A. Wood, and C. F. Thurston, "The structure of laccase protein and its synthesis by the commercial mushroom Agaricus bisporus," Journal of General Microbiology, vol. 139, no. 1, pp. 171-178, 1993.

[17] V. M. Halaburgi, S. Sharma, M. Sinha, T. P. Singh, and T. B. Karegoudar, "Purification and characterization of a thermostable laccase from the ascomycetes Cladosporium cladosporioides and its applications," Process Biochemistry, vol. 46, no. 5, pp. 1146-1152, 2011.

[18] P. Zucca, A. Rescigno, A. Olianas, S. Maccioni, F. A. Sollai, and E. Sanjust, "Induction, purification, and characterization of a laccase isozyme from Pleurotus sajor-caju and the potential in decolorization of textile dyes," Journal of Molecular Catalysis B, vol. 68, no. 2, pp. 216-222, 2011.

[19] G. Palmieri, G. Cennamo, V. Faraco, A. Amoresano, G. Sannia, and P. Giardina, "Atypical laccase isoenzymes from copper supplemented Pleurotus ostreatus cultures," Enzyme and Microbial Technology, vol. 33, no. 2-3, pp. 220-230, 2003. 
[20] S. B. Younes and S. Sayadi, "Purification and characterization of a novel trimeric and thermotolerant laccase produced from the ascomycete Scytalidium thermophilum strain," Comparative Biochemistry and Physiology B, vol. 73, no. 1-4, pp. 35-42, 2011.

[21] D. D. Hu, R. Y. Zhang, G. Q. Zhang, H. X. Wang, and T. B. $\mathrm{Ng}$, "A laccase with antiproliferative activity against tumor cells from an edible mushroom, white common Agrocybe cylindracea," Phytomedicine, vol. 18, no. 5, pp. 374-379, 2011.

[22] M. Li, G. Zhang, H. Wang, and T. Ng, "Purification and characterization of a laccase from the edible wild mushroom Tricholoma mongolicum," Journal of Microbiology and Biotechnology, vol. 20, no. 7, pp. 1069-1076, 2010.

[23] H. X. Wang and T. B. Ng, "A novel laccase with fair thermostability from the edible wild mushroom (Albatrella dispansus)," Biochemical and Biophysical Research Communications, vol. 319, no. 2, pp. 381-385, 2004.

[24] H. X. Wang and T. B. Ng, "A laccase from the medicinal mushroom Ganoderma lucidum," Applied Microbiology and Biotechnology, vol. 72, no. 3, pp. 508-513, 2006.

[25] P. Baldrian and J. Gabriel, "Copper and cadmium increase laccase activity in Pleurotus ostreatus," FEMS Microbiology Letters, vol. 206, no. 1, pp. 69-74, 2002.

[26] Y. R. Wu, Z. H. Luo, R. Kwok-Kei Chow, and L. L. Vrijmoed, "Purification and characterization of an extracellular laccase from the anthracene-degrading fungus Fusarium solani MAS2," Bioresource Technology, vol. 101, no. 24, pp. 97729777, 2010.

[27] T. B. Ng, "Peptides and proteins from fungi," Peptides, vol. 25, no. 6, pp. 1055-1073, 2004.

[28] Y. J. Zou, H. X. Wang, T. B. Ng, C. Y. Huang, and J. X. Zhang, "Purification and characterization of a novel laccase from the edible mushroom Hericium coralloides," The Journal of Microbiology, vol. 50, no. 1, pp. 72-78, 2012.

[29] M. Böttcher and F. Grosse, "HIV-1 protease inhibits its homologous reverse transcriptase by protein-protein interaction," Nucleic Acids Research, vol. 25, no. 9, pp. 1709-1714, 1997.

[30] H. X. Wang and T. B. Ng, "A new laccase from dried fruiting bodies of the monkey head mushroom Hericium erinaceum," Biochemical and Biophysical Research Communications, vol. 322, no. 1, pp. 17-21, 2004.

[31] T. B. Ng and H. X. Wang, "A homodimeric laccase with unique characteristics from the yellow mushroom Cantharellus cibarius," Biochemical and Biophysical Research Communications, vol. 313, no. 1, pp. 37-41, 2004. 

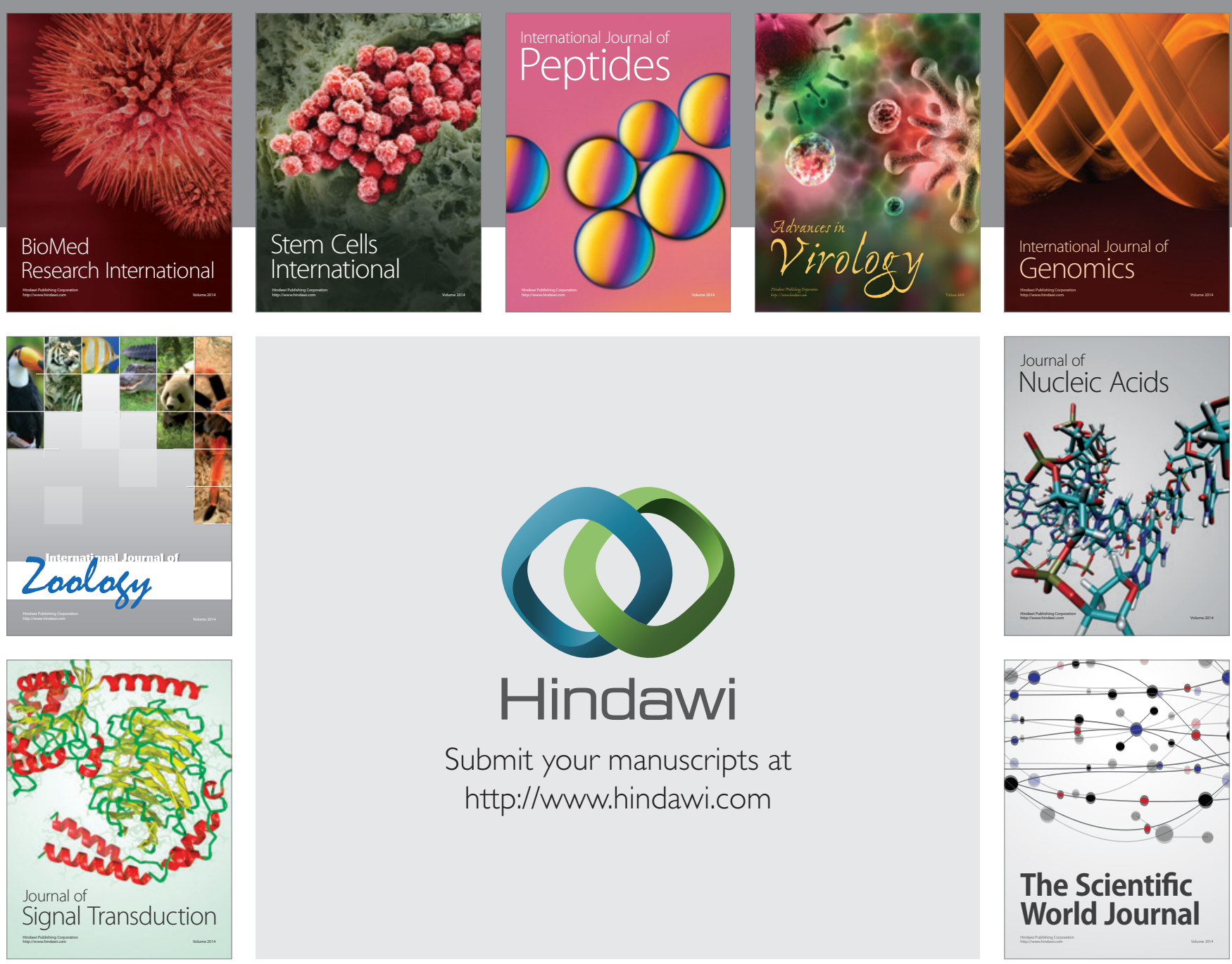

Submit your manuscripts at

http://www.hindawi.com
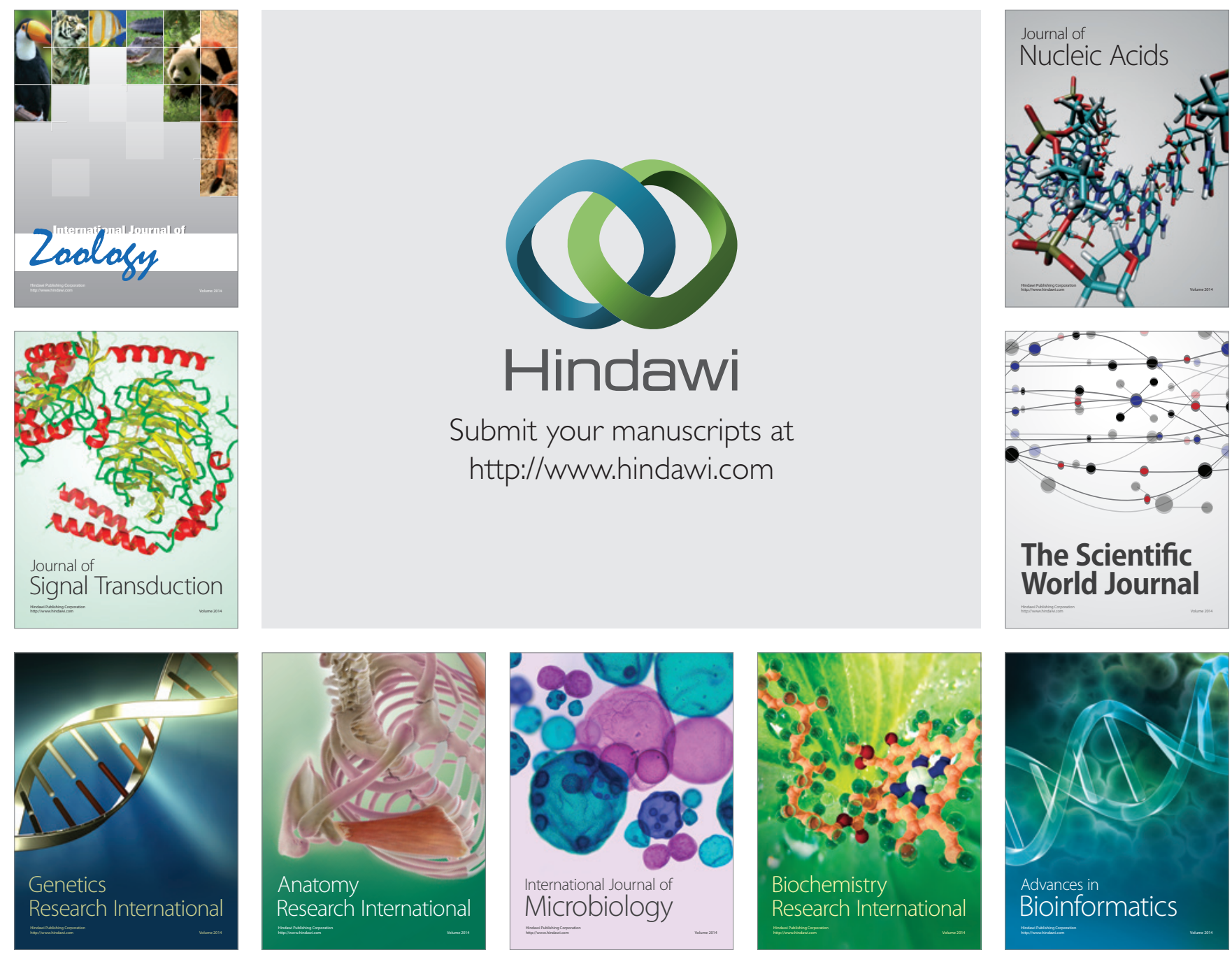

The Scientific World Journal
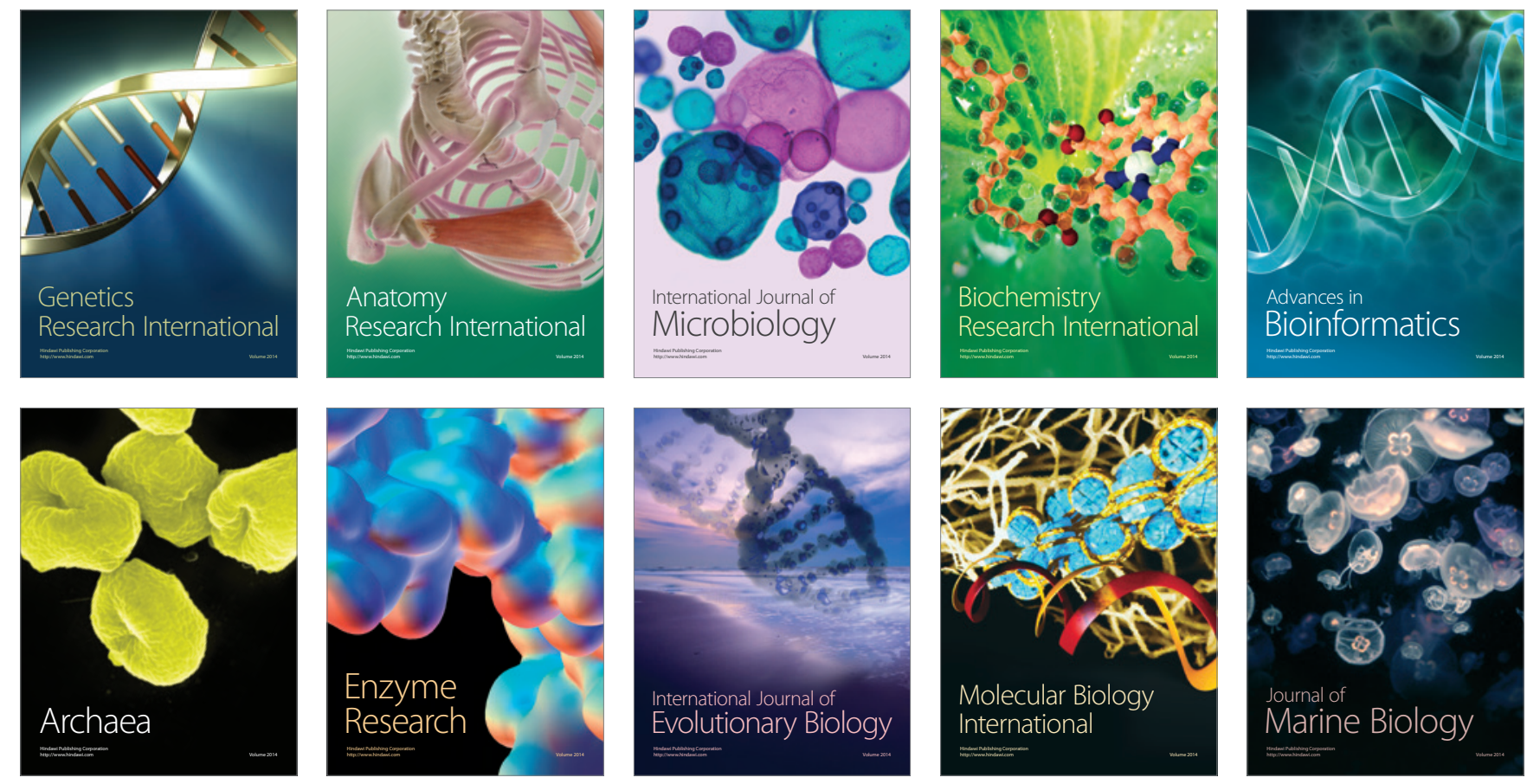